\title{
THE DETERMINANTS OF E-LEARNING USAGE BY TEACHERS OF VOCATIONAL HIGH SCHOOLS IN THE YOGYAKARTA SPECIAL REGION
}

\author{
Priyanto \\ Faculty of Engineering, Universitas Negeri Yogyakarta \\ priyanto@uny.ac.id \\ Herminarto Sofyan \\ Faculty of Engineering, Universitas Negeri Yogyakarta \\ hermin@uny.ac.id \\ Herman Dwi Surjono \\ Faculty of Engineering, Universitas Negeri Yogyakarta \\ hermansurjono@uny.ac.id
}

\begin{abstract}
The purpose of the study was to find the determinants of e-learning implementation by teachers of vocational school in the Yogyakarta Special Region. The research objective was achieved by describing the essential influence of social environment and facilitating conditions toward the technology acceptance model of e-learning. The study was a correlational research one with an expost facto approach. The number of research sample was 132 teachers and the research sample was determined by the Krejcie \& Morgan formula. The research sample was distributed by means of proportional random sampling technique. The primary data source was the teachers' self report which had been collected by using a questionnaire. The observation and the open-ended interviews were conducted in order to support the primary data. The content validity was assessed by means of expert judgment and the construct validity was calculated by means of Pearson correlation. The reliability was determined by means of Cronbach's Alpha minimum value namely 0.70. The data analysis was performed by using path analysis at a significance level of 0.05. The study concluded that the effect of social environment and facilitating conditions to the e-learning usage had been mediated by three main variables of Technology Acceptance Model (TAM), namely perceived usefulness, perceived ease of use, and intention to use.
\end{abstract}

Keywords: E-learning, technology acceptance model, social environment, facilitating conditions.

\section{DETERMINAN PENGGUNAAN E-LEARNING OLEH GURU SMK DI DAERAH ISTIMEWA YOGYAKARTA}

\begin{abstract}
Abstrak
Studi ini bertujuan untuk mengetahui faktor determinan penggunaan e-learning oleh guru SMK di Daerah Istimewa Yogyakarta. Tujuan ini dicapai dengan cara menjelaskan hakikat pengaruh lingkungan sosial sekolah dan kondisi fasilitas teknologi terhadap model penerimaan teknologi elearning. Studi ini merupakan penelitian korelasional bersifat ex-post facto. Sampel penelitian sebanyak 132 guru ditentukan menggunakan formula Krejcie \& Morgan didistribusikan dengan teknik proportional random sampling. Sumber data primer adalah laporan diri guru, dikumpulkan menggunakan kuesioner. Observasi dan wawancara terbuka dilakukan sebagai pendukung data primer. Validasi isi dilakukan dengan expert judgment dan validasi konstruk dilakukan dengan korelasi Pearson. Reliabilitas ditentukan dengan dengan nilai Cronbach's Alpha minimal 0,70. Analisis data dilakukan dengan analisis jalur pada taraf signifikansi 0,05. Hasil studi menunjukkan pengaruh lingkungan sosial dan kondisi yang memfasilitasi terhadap penggunaan elearning dimediasi oleh tiga variabel utama model penerimaan teknologi, yaitu kegunaan, kemudahan penggunaan, dan intensi.
\end{abstract}

Kata kunci: e-learning, model penerimaan teknologi, lingkungan sosial, kondisi yang memfasilitas. 


\section{INTRODUCTION}

The explosive development of information and communication technology (ICT) has changed all of the life aspects including the education. The space of global information that is created by the ICT has been the characteristics of modern people development and has changed the industries of manufacture, service and labor. Consequently, such situation brings about changes in the job characteristics and the labor qualification. Zarini et al. (2009, p.1835) states that the recent vocational education system should be modified in order to meet the new demands within any occupation namely the labors who possess the combination of developmentallyrelevant skills and attitudes.

The modernization of vocational education should emphasize the development of skills in addition to the development of technology innovation that supports the new life style namely the information era (Kostik et al., 2009, p.1897). In order to answer the challenge, Cheng (2005) emphasizes the importance of paradigm switching in the educational reformation by transforming the space-bound traditional paradigm to the new paradigm called triplization in the form of web-based learning or e-learning.

Electronic learning (E-Learning) is one of the ICT implementations in the learning process. E-Learning is a learning content distribution or a learning experience share electronically by using computer and computer-based media (Smaldino et al., 2008) in which the learning content might be distributed through the web (the Internet), the $\mathrm{CD}$ or the DVD (Davidson-Shivers \& Rasmussen, 2006). Furthermore, Smaldino et al. (2008) states that e-learning might monitor the students' performance and might report the students' development.

The explanation above asserts that the educational modernization that pays attention to individual, local and global aspects might be performed by means of Internet and elearning. In this case, e-learning does not become the targeted object (learning about elearning); instead, e-learning is positioned as the facilities that will be used for the learning process.

The e-learning in line with the Strategic Plan that has been implemented by the
Ministry of Culture and Education. In the Strategic Plan 2005-2009 the Ministry of Culture and Education stated that the department would always develop the benefits of ICT operation for the school learning and information system including the electronically-developed learning process (Depdiknas, 2006). Furthermore, in the Strategic Plan 2010-2014 the Ministry of Culture and Education has decided that the Strategic Target would be in 2014 the Ministry should achieve the $70 \%$ e-learning implementation in the vocational high schools.

The researchers performed an initial study in two vocational high schools located in the Yogyakarta Special Region namely SMK 2 Depok Sleman and SMK YAPPI Gunung Kidul; the initial study was performed in 2012. The results of the initial study showed that only $10 \%$ of the teachers in both vocational high schools benefitted the elearning process whereas the schools had provided sufficient facility for the e-learning process. The next study stated that in 2013 there had only been $6.15 \%$ vocational high schools in the Yogyakarta Special Region that had the e-learning online web sites.

Looking at the Strategic Target that the Ministry of Culture and Education has, namely that $100 \%$ vocational high schools have Internet access and 70\% vocational high schools implement the e-learning activities, the condition in the Yogyakarta Special Region is still under the expectation. The condition, as a result, describes the low elearning implementation in the schools (Priyanto, 2009, p.87). The situation has also been confirmed by Sahin (2010, p.253) who states that although the technology has been widely spread most of the schools have still been left behind because of the lack of integration between the technology and the lesson in the classroom.

Bhuasiri et al. (2012, p.846) identify the determining factors that influence the acceptance of e-learning system in the developing countries. These factors are divided into three main dimensions namely: the school's system dimension, the school's personal dimension and the school's social environment dimension. The system dimension consists of system quality, information quality and service quality. Then, the personal dimension refers to the teacher's attitude, teaching style and ICT 
competence (Keramati, 2012, p.1921). Next, the social environment dimension includes the coercive, normative, and mimesis pressure (Jan et al., 2012, p.330). These opinions assert that the e-learning development in the schools does not only include the technology facilities and teacher's competency but also the social environment in which a system exists. On the other hand, the school's social environment dimension that became the school's culture had not been given attention and recognition.

According to the psychological perspective, social psychology divides the attitudes into three components namely: cognitive components (perceptive neuron response and verbal statement from belief); affective components (sympathetic neuran response and verbal statement from action); and connative components (open action and verbal statement toward behavior) (Fishbein \& Ajzen, 1975; Nairne, 2009). The conceptualization of the three components is commonly defined as the theory of attitude tripartite.

The attitude tripartite becomes the basis of Technology Acceptance Model (TAM), which has been intertwined in the Davis' internal inter-psychological variable relationship (1989). The cognitive component is created by two beliefs the ease of operation and the operation, the affective component is created by the attitude toward the operation and the attitude component is created by the intention toward the operation (Davis et al., 1989, p.985). However, in the TAM that has been revised Davis (1983, p.481) eliminates the affective component in explaining the behaviors of technology acceptance. In general, TAM is accepted as a valid model for predicting the individual accepting behaviors within the multiple information technology and the use of the technology (Tseng et al., 2013, p.16). A meta-analytical study shows that TAM has been used by $90 \%$ researchers in a study of e-learning technology acceptance (Sumak et al., 2011, pp.32-33).

In relation to the social environment, several studies show that the social environment factors heavily influence the teacher's attitude toward the use of e-learning (Jan, 2012, p.336; Chang \& Yang, 2012, p.11). Meanwhile, the intention toward the use of ICT is the main predictor in the actual operation (Fishbein \& Ajzen, 1975; Davis et al., 1989; p.985). Consequently, although the teachers have been given training programs they tend to use the old-fashion manner in the daily life whereas the hardwares and the softwares have been avalable.

The situation above has been in accordance with the statement that the adoption of e-learning demands cultural acceptance that might be realized into a cultural change or a re-culturing process (Cavanagh \& Reynolds, 2004, p.4). In order that the teachers fully implement the ICT into the learning process, the teachers should attain paedagogical, social, cultural and emotional support (Ming et al., 2010, p.6). Therefore, within the elearning development there should be good and comprehensive strategies in order to cover the organizational multidimensions. This matter implies that in the e-learning development focus on the technology has not been sufficient, so there should be other focus on the teacher and the environment in which the learning process occurs. The comprehensive strategy becomes the main consideration within the study.

The preliminary study that has been done in the schools indicate that the e-learning development is still in the partial setting or, in other words, the e-learnig development is limited to the technology and the teacher training. The teachers' personal attitudes and the social factors that influence the attitude have not been given serious attention.

In order to have effective and sustainable implementation within the realization of educational modernization toward the vocational education, there should be a comprehensive study before the e-learning process will be implemented. In addition to the technological factors, there should be analysis toward the non-technological needs that include: (1) psychological readiness; (2) sociological readiness; and (3) environmental readiness (Chapnick, 2000). However, up to date the study has not been performed especially in terms of e-learning development in Indonesia whereas the three factors influence the use of e-learning in the schools.

Departing from the existing discrepancy, the researchers conclude that there should be an in-depth review toward the determining factors of e-learning usage by the teachers with the TAM as the main or the core model. The study will explain the teachers' psychological readiness in the e-learning 
adoption and use within the vocational high schools from the perspective of social environment and technology altogether with the accompanying attributes. The study does not only discuss the adoption process only but also to maintain the sustainability of e-learning implementation in the vocational high schools.

The study focuses on two aspects namely: (1) the development of external variables in the social environment and the facilitating conditions that become the antecedent of TAM; and (2) the configuration of external inter-variable relationships and the TAM variables. The indicators of social environment variables will be explored according to the existing school cultures in Indonesia. The facilitating conditions will be developed by exploring each of the indicators according to the specific needs for implementing the elearning system. The external variable relationships and the basic model will be analyzed by combining the TAM theory and the other existing theories.

The study in general is to find the determining factors of e-learning implementation by the teachers of vocational high schools in the Yogyakarta Special Region. In detail, the study objectives are to: (1) find the direct and the indirect influences of social environment variables toward the e-learning acceptance in the vocational high schools; (2) find the direct and the indirect influences of facilitating conditions toward the e-learning technology acceptance model in the vocational high school; and (3) explain the definition of the school's social environment influence and the technology-facilitating conditions toward the e-learning technology acceptance model in the vocational high schools.

\section{RESEARCH METHOD}

The research was an ex-post facto correlational one and was to find the determinants of e-learning implementation by the teachers of vocational high schools and to test the inter-variables relationship. In order to achieve the objectives, the researchers measured the respondents' perception toward the other variables that the researchers assumed to have great influence. The results that the researchers attained was the fundamental inter-variables relationship.
The research population was the vocational high school teachers who had attended the e-learning training program and the number of the respondents was 200 people. The teachers had the background of the productive and the adaptive group from the following two study programs: technology and engineering. The sample size of 132 teachers was distributed by means of proportional random sampling technique namely by distributing proportionally the number of teachers who had attended the training program from each county/city.

The primary data source in the research was a self-report that had been gathered individually from the teachers. The form of the instruments that the researchers used was questionnaire. In order to support the data attained from the questionnaire, the researchers also performed an open-ended interview and an observation.

The researchers performed the measurement validity in two stages namely the content validity and the construct validity. In the first stage, the content validity was measured by finding the opinions from the experts (expert judgment) namely the experts' consideration about the instrument guidelines. The experts were asked whether the instrument guidelines had represented the measured substance or not. The experts who had been involved in the research were from the education sector, the information technology sector and the practitioners as the providers of e-learning service in the Yogyakarta Special Region. The experts' opinions and suggestions would be used as the basis for revising the instrument.

In the second stage, after the model had been revised, the researchers performed an experiment toward the instrument to 30 respondents from the research population. The analysis that the researchers employed in the construct validity measurement was correlating the score of each statement items to the total score of the item by means of product moment correlation with significant rate at $5 \%$. If the correlation was positive with the minimum coefficient at 0.3 , then the factor would be a strong construct. On the contrary, if the correlation was negative with the minimum coefficient at 0.3 , then the factor would be classified as invalid and, as a result, the factor should be revised. 
The data analysis techniques that the researchers employed were a descriptive analysis and an inferential data analysis. The inferential analysis that the researchers implemented was path analysis and the path analysis was used in order to test the hypothesis with the significant rate at 0.05 . Before testing the hypothesis, the researchers performed a normality test, a linearity test, a homoscedasticity test and a multicolinearity test as the analysis requirements.

\section{RESULTS AND DISCUSSIONS}

The data description was presented in the form of categorical frequency distribution based on the classification of E-Learning Readiness Score which had been adapted from the e-Learning Readiness Score (e-LRS) (Aydin \& Tasci, 2005). The e-LRS had been made as the reference. Then, the data description for the six variables was presented as follows.

The social environment (SE) showed that $11 \%$ respondents had been prepared, $43 \%$ respondents had been unprepared and 49\% respondents had been very unprepared. The situation showed that in general the teachers' perception toward the social environment was classified as unprepared.

The facilitating conditions (FC) showed that $15 \%$ respondents had been very prepared, $50 \%$ respondents had been prepared, 33\% respondents had been unprepared and 3.20\% respondents had been very unprepared. The situation implied that in general the teachers' perception toward the technology facilitating conditions was classified as prepared.

The perceived usefulness (PU) showed that $27 \%$ respondents had been very prepared, $43 \%$ respondents had been prepared, $23 \%$ respodents had been unprepared and $7 \%$ respondents had been very unprepared. The situation showed that in general the teachers' perception toward the e-learning use was classified as prepared.

The perceived ease of use (PEOU) showed that $24 \%$ respondents had been very prepared, $47 \%$ respondents had been prepared, $18 \%$ respondents had been unprepared and $11 \%$ respondents had been very unprepared. The situation showed that in general the teachers' perception toward the ease of operation was classified as prepared.
The intention to use (IU) showed that $21 \%$ respondents had been very prepared, $38 \%$ respondents had been prepared, $27 \%$ respondents had been unprepared and 14\% respondents had been very unprepared. The situation showed that in general the intention of operating the e-learning system was classified as prepared.

The e-learning usage showed that $7 \%$ respondents had been very prepared, $16 \%$ respondents had been prepared, $42 \%$ respondents had been unprepared and 35\% respondents had been very unprepared. The situation showed that in general the use of e-learning was classified as very unprepared.

The descriptive analysis had provided the descriptions of research variables that showed the readiness from the perspective of e-learning readiness scale. As a matter of reference, the researchers employed variables that had 8 question items with 8 as the smallest point and 32 as the biggest point; the score of e-readiness that the researchers yielded was 22.4. The results of visualization toward six variables with three indicators for the social environment and with four indicators for the technology facilitating conditions were shown in Figure 1.

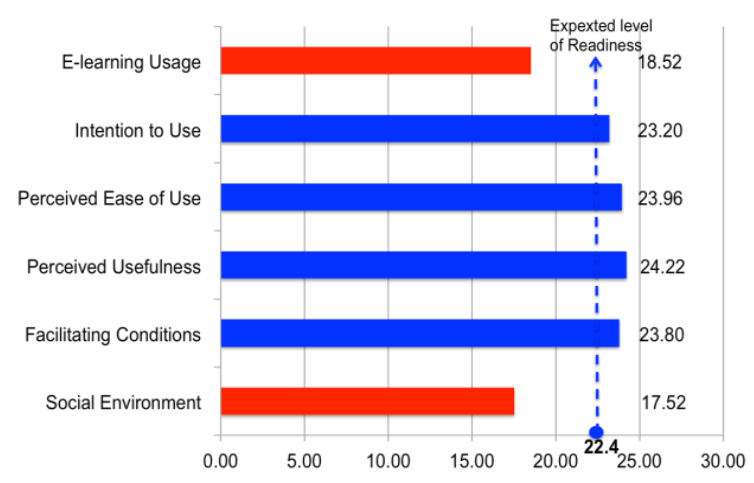

Figure 1. The Mean Score of Research Variables toward the e-LRS

From the mean score, the technologyfacilitating conditions reached the top limit of e-readiness score and teacher readiness earned the highest mean score followed by technology facility and compatibility. The finding showed that the training given to the teachers had made the teachers prepared as well as the technology facility that they should master. The other variables that showed the readiness were the ease of operation, the use and the intention. 
The study employed the TAM model as the core variable that would be expanded by two external variables as the antecedents. The TAM variables consisted of PEOU, PU, IU and e-learning usage. The external variables consisted of the facilitating conditions and the social environment.

The determinants of e-learning use by the vocational high school teachers might be identified by testing the hypothesis that had been formulated hierachically as follows: $\left(\mathrm{H}_{1}\right)$ The social environment and perceived ease of use will have positive effects on perceived usefulness of e-learning; $\left(\mathrm{H}_{2}\right)$ The facilitating conditions will have positive effects on perceived ease of use of e-learning; $\left(\mathrm{H}_{3}\right)$ The social environment, perceived usefulness and perceived ease of use will have positive effects on the intention to use of e-learning; and $\left(\mathrm{H}_{4}\right)$ The intention to use and the facilitating conditions will have positive effects on the e-learning usage. The four hypothesis were formulated by the sub-structure 1 , the sub-structure 2 , the sub-structure 3 and the sub-structure 4 regression model.

The results of analysis toward the substructure 1 showed that $F_{\text {count }}(54,552)>F_{\text {table }}$ $(3,70)$ and $p=0.000$. These results, referring to $\mathrm{H}_{1}$ which stated that the social environment and perceived ease of use will have positive effects on perceived usefulness of e-learning, were acceptable. The two variables were able to explain that the intention to use had influence for about $45 \%$.

Then, the results of analysis toward the sub-structure 2 showed that $\mathrm{F}_{\text {count }}(70,434)>$ $\mathrm{F}_{\text {table }}(3,91)$ and $\mathrm{p}=0.000$. These results, referring to $\mathrm{H}_{2}$ which stated that he facilitating conditions will have positive effects on perceived ease of use of e-learning, were acceptable. These variables were able to explain that the perceived ease of use had influence for about $34.60 \%$.

Next, the results of analysis toward the sub-structure 3 showed that $\mathrm{F}_{\text {count }}(30,498)>$ $F_{\text {table }}(2,68)$ and $p=0.000$. These results, referring to $\mathrm{H}_{3}$ which stated that the social environment, perceived usefulness and perceived ease of use will have positive effects on the intention to use of e-learning, were acceptable. The three variables were able to explain that the intention to use had influence for about $40.3 \%$.
Furthermore, the results of analysis toward the sub-structure 4 showed that $\mathrm{F}_{\text {count }}$ $(21,093)>F_{\text {table }}(3,70)$ and $p=0.000$. These results, referring to $\mathrm{H}_{4}$ which stated that the intention to use and the facilitating conditions will have positive effects on the e-learning usage, were acceptable. The two variables were able to explain that the e-learning usage had influence for about $23.5 \%$.

The results of the analysis toward the four multiple regression sub-structures would be presented in the Table 1 .

Table 1. The Simultaneous Influence of Independent Variables toward the Dependent Variables

\begin{tabular}{|c|c|c|c|c|}
\hline \multicolumn{2}{|c|}{ Variables } & \multirow[b]{2}{*}{$\begin{array}{l}\text { Adjusted } \\
\mathrm{R} \text { square }\end{array}$} & \multirow[b]{2}{*}{$\mathrm{F}$} & \multirow[b]{2}{*}{ Sig. F } \\
\hline $\begin{array}{c}\text { Indepen- } \\
\text { dents }\end{array}$ & $\begin{array}{c}\text { Indepen- } \\
\text { dents }\end{array}$ & & & \\
\hline PU & $\begin{array}{c}\text { SE } \\
\text { PEOU }\end{array}$ & 0,458 & 54,552 & 0,000 \\
\hline PEOU & $\mathrm{FC}$ & 0,351 & 70,434 & 0,000 \\
\hline IU & $\begin{array}{c}\text { SE } \\
\text { Usage } \\
\text { PEOU }\end{array}$ & 0,417 & 30,498 & 0,000 \\
\hline Usage & $\begin{array}{l}\text { IU } \\
\text { FC }\end{array}$ & 0,246 & 21,093 & 0,000 \\
\hline
\end{tabular}

An evaluation toward the inter-variable influence between the dependent variable and the independent variable had partially been done by using the path coefficient $(\beta)$ value and t-value. The inter-variable influence between the dependent variable and the independent variable had partially been summarized in Table 2. The summary of Table 1 and Table 2 , then, was visualized into the the form of empiric sub-structural model in Figure 2.

Table 2. The Partial Influence of Independent Variables toward the Dependent Variables

\begin{tabular}{|c|c|c|c|c|}
\hline \multicolumn{5}{|c|}{ Variables } \\
\hline $\begin{array}{c}\text { Depen- } \\
\text { dents }\end{array}$ & $\begin{array}{l}\text { Indepen- } \\
\text { dents }\end{array}$ & $\beta$ & $\mathrm{t}_{\text {count }}$ & $p$ \\
\hline \multirow{2}{*}{ PU } & SE & 0,184 & 2,726 & 0,007 \\
\hline & PEOU & 0,601 & 8,878 & 0,000 \\
\hline PEOU & $\mathrm{FC}$ & 0,593 & 8,392 & 0,000 \\
\hline \multirow{3}{*}{ IU } & SE & 0,162 & 2,232 & 0,027 \\
\hline & Usage & 0,348 & 3,800 & 0,000 \\
\hline & PEOU & 0,277 & 3,102 & 0,002 \\
\hline \multirow{2}{*}{ Usage } & IU & 0,342 & 3,612 & 0,000 \\
\hline & $\mathrm{FC}$ & 0,210 & 2,219 & 0,028 \\
\hline
\end{tabular}




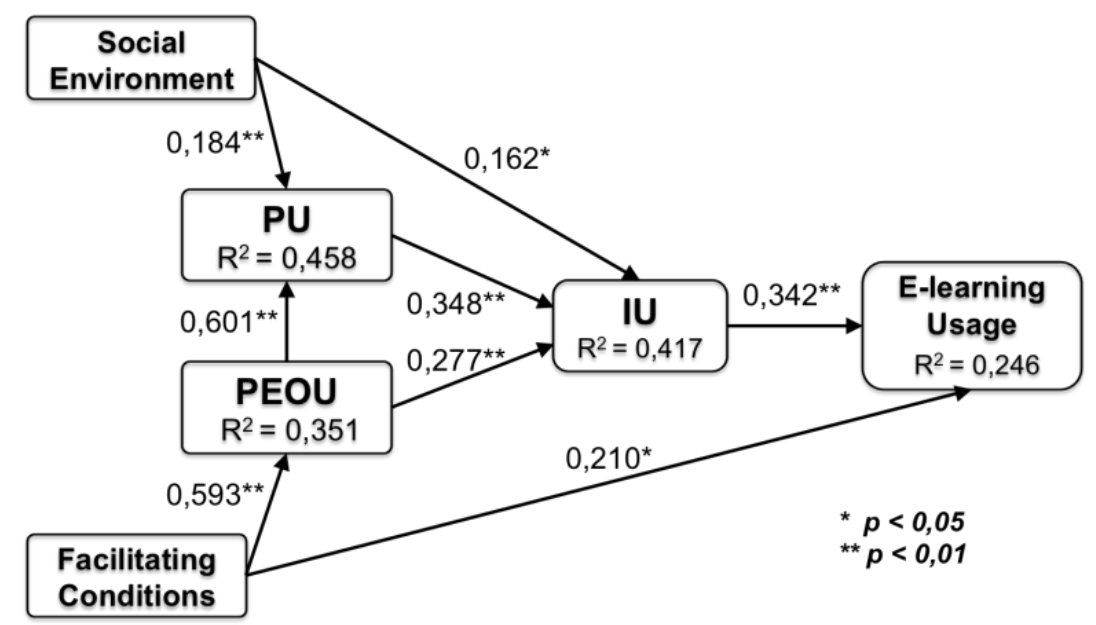

Figure 2. The Empirical Structural Model of E-Learning Use

The hypothesis testing had shown the direct and the indirect inter-variable relationship by means of positive and significant path coefficient at the significance rate less than $5 \%$. Then, the summary of inter-variable relationship in the form of direct, indirect and total influence would be presented in Table 3 as follows.

Table 3. Direct, Indirect and Total Influence

\begin{tabular}{clccc}
\hline TAM & Deter- & & Influence \\
Variables & minants & Direct & Indirect & Total \\
\hline PU & SE & 0,184 & -- & 0,184 \\
& PEOU & 0,601 & -- & 0,601 \\
& FC & -- & 0,356 & 0,356 \\
PEOU & FC & 0,593 & -- & 0,593 \\
IU & SE & 0,162 & 0,064 & 0,226 \\
& Usage & 0,348 & -- & 0,348 \\
& PEOU & 0,277 & 0,209 & 0,486 \\
& FC & -- & 0,288 & 0,288 \\
Usage & IU & 0,342 & -- & 0,342 \\
& FC & 0,210 & 0,099 & 0,309 \\
& SE & -- & 0,076 & 0,076 \\
& Usage & -- & 0,119 & 0,119 \\
& PEOU & -- & 0,166 & 0,166 \\
\hline
\end{tabular}

In Table 3, the four variables of technology acceptance model, namely PEOU, the $\mathrm{IU}$, and the usage, had determinants with different total influence. The strength of determinant for each variable of TAM might be explained as follows: (1) the PU had the strongest determinant on the factor of PEOU with the total influence $=0.601$; $(2)$ the PEOU had the second strongest determinant on the factor of facilitating conditions with the total influence $=0.593 ;$ ( 3 ) the intention to use had the strongest determinant on the factor of PEOU with the total influence $=0.486$; and (4) the e-learning usage had the strongest determinant on the factor of intention to use with the total influence $=0.342$.

The results of path analysis showed that the strongest determinant on the use of elearning was IU; meanwhile, the strongest determinant on the intention to use was the elearning usage. However, from the total influence the strongest determinant on the intention to use was PEOU. These findings had been in accordance with the postulation of Davis et al. (1989, p.997) which stated that in TAM the IU had been the main predictor for the usage. The TAM model had three main variables for that might be used for measuring the users' behaviors in the real application namely: the PEOU, PU and IU. Therefore, the researchers might conclude that TAM might mediate the influence of the social environment and the facilitating conditions toward the e-learning usage well.

\section{The Determinant of Perceived Ease of Use}

The determinant of perceived ease of use is the facilitating conditions. The results of the study showed that the facilitating conditions, consisting of the indicators of teacher competence, e-learning compatibility to the learning process, technology facility, and technical support, altogether caused the teacher to sense the PEOU of e-learning. 
These findings had been in accordance discretely with the study by several researchers in the past in terms of direct influence toward the perceived ease of use, which had not completely summarized the facilitating conditions; instead, the direct influence had been summarized from each indicator of the facilitating conditions.

The teacher competence toward the elearning referred to the technical competence that might be observed and might be measured (Chapnick, 2000). Teachers' skills were a very important factor in the adoption of elearning in the schools because the teachers had the central role as the final users. Therefore, the success of educational innovation depended heavily on the teachers' knowledge and skills. Similarly, the problem that inhibited the use of computer in the schools for most of the time was the teachers' lack of knowledge and skill. The teachers' competence in operating the e-learning and the supporting software had direct influence toward the perceived ease of use and the finding had been in accordance with a study by Roca \& Gagne (2008, p.1596).

E-learning compatibility referred to how far an innovation had been considered as consisten to the existing values, the demands and the past experiences of the potential adopters (Moore \& Benbasat, 1991, p.195). In the implementation, the compatibility assessed the level of appropriateness between the new technology and the multiple individual aspects and in which situation the technology would be used (Karahanna et al., 2006, p.782). Both opinions indicated that whether the e-learning had high compatibility in the teachers' daily task might yield better elearning adoption or not. The compatibility had a direct influence toward the perceived ease of use and the finding had been in accordance with the study by Venkatesh \& Davis (2000, p.196).

Technology facility referred to the possession of appropriate equipment and was a main precondition in the e-learning implementation; as a result, the technology facility should be planned well (Khan, 2005). Technology readiness was an absolute precondition for the e-learning development in the school. The readiness itself consisted of meeting the minimum requirements, meeting the minimum quality and meeting the minimum quantity. The quantity would determine the level of user access toward the technology both access to the computer and access to the intranet and the Internet. The technology facility had a direct and significant influence toward the ease of operation and the finding had been in accordance with a study by Venkatesh \& Bala (2008, p.291).

Technical support became a very important factor in the e-learning adoption because it had a big role in the management of available infrastructure. Technical support played a role in installing and in managing the technology infrastructure of hardware and software, in providing technical training related to the e-learning and in providing technical support if the users had problems (Alenezi et al., 2011, p.6). The technical support had a direct and significant inf; uence toward the ease of operation and the finding had been in accordance with a study by Teo (2009, p.209) and Aypay et al. (2012, p.269).

\section{The Determinant of Perceived Usefulness}

The direct determinants on the variable perceived usefulness were the perceived ease of use and the social environment; both of these determinants had significant influence toward the perceived usefulness. Partially, the perceived ease of use and the social environment had significant influence toward the perceived usefulness. The finding showed that the perceived ease of use was the strongest determinant for the use compared to that of social environment.

Perceived ease of use was the individual level of trust in terms of using certain system would make him or her free of big problems or great efforts (Davis, 1989, p.320). The perceived ease of use was known as a level of business expectation in relation to the level of ease of system operation in relation to the technology acceptance; the easier the application might be operated the higher the tendency that user would accept the application would be. The perceived ease of use had direct influence toward the use and the finding had been in accordance with a study by Davis (1993, p.481), Teo (2009, p.209), Aypay et al. (2012, p.269) and Coskuncay \& Ozkan (2013, p.20). The finding showed that the easier the e-learning operation the more beneficial the e-learning would be sensed by 
the teachers in terms of improving teachers' productivity and effectiveness.

Social environment had three indicators namely coercive pressure, normative pressure and mimetic pressure (DiMaggio, 1983, p.150). Coercive pressure referred to the support from the leader and the other figures who had any position higher than the teacher. The leader's support was realized in the form of the schools' vision and mission and the leader's more operation support was realized in the form of regulation-making. Normative pressure referred to the colleague support in operating a technology. In the e-learning context, normative pressure showed that individuals would be more possible to adopt the elearning if most of these individuals considered that most of their peers had adopted the e-learning system (Jan et al., 2012, p.331). Mimetic pressure depicted how far the operated innovation had been perceived as being able to improve one's status within a social system (Moore \& Benbasat, 1991, p.195).

Social environment had direct influence toward the perceived usefulness and the finding had been in accordance with the study by Yang \& Choi (2001, p.518), Atif et al. (2012, p.6) and Coskuncay \& Ozkan (2013, p.20). Another study by Venkatesh \& Davis, 2000 , p.197) stated that coercive pressure and mimetic pressure had significant influence toward the perceived usefulness. This matter implied that the higher the support from the principal, was the more the peers would use elearning, and and reward for teachers who use e-learning, e-learning it will be perceived more useful.

The facilitating conditions had indirect and significant influence toward perceived usefulness and this matter showed that the facilitating conditions might improve the individual trust toward the e-learning; as a result, the users, in this case the teachers, would sense the higher PEOU. The easier the e-learning was operated, it will perceive more useful, such situation had been the the users' behavior toward the e-learning system.

\section{The Determinant of Intention to Use}

Intention to use was possessed by all of the technology acceptance model theories except the social cognitive theory (SCT). In the theory of reasoned action (TRA) model (Fishbein \& Ajzen, 1975), the TAM (Davis,
1989) and the theory of planned behavior (TPB) (Ajzen, 1991), the intention to use had been the most influential predictor toward the behaviors. On the other hand, Chapnick (2000) and Yun \& Murad (2006, p.2135) stated that the intention referred to the psychological readiness of information system final users and had been the main factor in the e-learning readiness that had the highest opportunity for the implementation process sabotage. Therefore, the researchers might conclude that the intention toward the use had become the main key of e-learning adoption by the teachers.

The results of the study showed that the direct determinants of intention to use were PEOU, perceived usefulness, and the social environment. The coefficient value of path analysis showed that the PU had been the strongest determinant and it was followed by perceived ease of use and social environment. The finding indicated that the teachers tended to had intention to use the e-learning if they perceive usefulness, ease of use, and social environment support.

The intention to use was defined as the level of individual trust in terms of using certain system would increase his or her performance (Davis, 1989, p.320). The finding on the determinant had been in accordance with a study by Venkatesh \& Davis (2000, p.197), Venkatesh \& Bala (2008, p.291), and Coskuncay \& Ozkan (2013, p.20). These studies concluded that the perceived usefulness would have greater influence toward the intention to use compared to that of perceived ease of use.

The finding also confirmed a study by Davis (1993, p.482), which stated that the perceived usefulness was the most influential and the most important determinant toward the system usage. Another study also stated that the use had been confirmed as the most important factor, which influenced the technology users acceptance and which had been the greatest concern from the previous researchers (Sun \& Zhang, 2006, p.59). Punnoose (2012, p.306) firmly stated that the perceived usefulness served as the key control form the intention and the users' behavior.

Social environment that had three indicators and that had significant influence toward the intention to use had been in accordance with a study by Atif et al. (2012, 
p.6), and Jan et al. (2012, p.335). The finding indicated that a better social environment would encourage the teachers' intention to use the e-learning.

Social environment and facilitating conditions had significant influence toward the intention to use through perceived usefulness. The influence of social environment and perceived ease of use toward the intention to use had been explained in the previous section. The finding implied that the better the social environment was and easier to operate e-learning, the teacher will perceive that elearning is more useful, in turn, can increase the intention to use e-learning.

\section{The Determinant of the E-Learning Usage}

The determinants of the e-learning usage was intentionto use and facilitating conditions. Partially, intention to use and facilitating conditions had significant influence toward the e-learning usage. The coefficient value of path analysis showed that the intention to use had been the strongest determinant for the e-learning use followed by the facilitating conditions. The finding indicated that the vocational high school teachers in the Yogyakarta Special Region had more tendency to use the e-learning if they had intention to use the e-learning compared to the facilitating conditions.

Intention to use had significant influence toward the e-learning usage had been in accordance with a study of TAM by Davis et al. (1989, p.993), Venkatesh \& Davis (2003, p.195), Venkatesh \& Bala (2008, p.280), and Tan et al. (2012, p.1027). However, the results of these studies might not be confirmed to those of the TAM studies because in the TAM, intention to use had been the single determinant for the usage.

Facilitating conditions had significant influence toward the e-learning usage and the finding had been in accordance with the study of TPB by Ajzen (1991, p.182) and the study of UTAUT by Venkatesh et al. (2003, p.447) and Workman (2014, p.116).

The finding of the study also supported the results of a study by Fishbein \& Ajzen (1975), which stated that the intention to use had been the main predictor of the usage, and a study by Davis et al. (1989, p.977), which postulated that the intention had been main predictor of the use. The postulate came from the conclusion of the study by Davis which stated, "People's computer use can be predicted reasonably well from their intentions."

In overall, from the results of path analysis the researchers might conclude that the strongest determinant for the e-learning use was intention to use. On the other hand, the strongest determinant on intentionto use was the perceived usefulness, followed by the PEOU and the social environment. However, from the total influence, the strongest determinant on the use was the perceived ease of use. The finding of the study had been in accordance with a study by Davis et al. (1989, pp.996-997), which stated that the three main insights for the determinant on the computer use were as follows: (1) the computer use might be predicted well from the intention; (2) the use had been the main determinant from the intention; and (3) the ease of operation had been the secondary determinant from the intention.

The finding of the study had confirmed that the three main variables of TAM might be used for measuring the users' behaviors in the real application and might explain the meaning of of social environment and facilitating conditions influence toward the TAM variables. Furthermore, the researchers might also conclude that social environment and facilitating conditions influence toward the use of e-learning had been well mediated by the three core variables of TAM namely the perceived ease of use, perceived usefulness, and the intention to use.

\section{CONCLUSIONS}

Social environment and facilitating conditions had significant influence toward the e-learning technology acceptance model in the vocational high schools both directly and indirectly. Social environment had significant influence toward the use and the intention. On the other hand, the use had greater influence toward the intention. The relationship showed that the influence of social environment toward the e-learning had been mediated well by the perceived usefulness and the intention to use.

Facilitating conditions had significant influence toward the ease of use and the elearning usage. Meanwhile, the influence of facilitating conditions toward the the e-learn- 
ing usage had been smaller than that of the intention. The relationship showed that the influence of facilitating conditions toward the e-learning had been mediated well by perceived ease of use, the perceived usefulness and the intention to use.

The two paradigms of these relationships confirmed that the influence of social environment and facilitating conditions toward the e-learning usage had been mediated well by the three main variables of the technology acceptance model namely the perceived ease of use, perceived usefulness, and the intention to use.

\section{Suggestions}

The results of the study implied that there had been several matters that should be revised in the strategies of implementing the e-learning system in the vocational high schools from the perspective of social environment and facilitating conditions. The provision of e-learning equipment in the schools up to date had given attention only to the equipment aspect (the hardware and the software) and the teachers' training. The provision of the equipment should be equipped with a study on the problems in the social environment. The discussion on the aspect of facilitating conditions showed that the technical support should be given more attention. The technical support included the technology and the paedagogy domain that would help the teachers if they had problems in the elearning implementation.

The schools should provide conducive social environment atmosphere toward the elearning implementation. The e-learning implementation should not only be regarded as voluntary suggestion. The support from the principals should be realized into regulations. The formation of e-learning user community both inside and outside the schools (or interschools) should be pursued as a catalisator for the mimesis process. The mimetic pressure might be realized by providing incentives for the teachers who use the e-learning system both in the form of material and/or social recognition.

The technology acceptance model in the study was not a fixed and unchanging model; instead, the model had been an open one especially for a continuous development. Any study in the future might change the technology acceptance model by expanding and/or modifying the model through the addition of other dimensions in order to have more external variables. The reason was that the results of the study were presumed to have other dimension that influenced the level of elearning acceptance in the vocational high schools throughout the Yogyakarta Special Region.

\section{REFERENCES}

Ajzen, I. (1991). The theory of planned behavior. Organizational behavior and human decision processes, 50, 179-211.

Atif, A., Richards, D. \& Bilgin, A. (2012, December). Predicting the Acceptance of Unit Guide Information Systems. Proceeding of $23^{\text {rd }}$ Australasian Conference on Information Systems Predicting Acceptance of Unit Guide IS, 1-10.

Aydin, C.H., \& Tasci, D. (2005). Measuring Readiness for e-learning: Reflections from an Emerging Country. Educational Technology \& Society, 8, 4, 244-257.

Aypay, A., Çelik, H.C. \& Aypay, A. et al. (2012). Technology acceptance in education: A study of pre-service teachers in turkey. The Turkish Online Journal of Educational Technology, 11, 4, 264-272.

Bhuasiri, W., Xaymoungkhoun, O., Zo, H., et al. (2012). Critical success factors for $e$ learning in developing countries: A comparative analysis between ICT experts and faculty. Computers \& Education, 58, 843-855.

Chapnick, S. (2000). Are you ready for elearning? Diambil 4 Januari 2008 dari http://www.learningcircuits.org/2000/nov 2000/chapnick.htm.

Chang, Y. \& Yang, C. (2012): Why do we blog? From the perspectives of technology acceptance and media choice factors. Behaviour \& Information Technology, iFirst article, 1-16.

Cheng, Y.C. (2005). New Paradigm for Reengineering Education. Netherlands: Springer. 
Davis, F.D., Bagozzi, R.P. \& Warshaw, P.R. (1989). User acceptance of computer technology: A comparison of two theoretical models. Management Science, $35,8,982-1003$.

Davis, F.D. (1989). Perceived usefulness, perceived ease of use, and user acceptance of information technology. MIS Quarterly, 13, 3, 319-340.

Davis, F.D. (1993). User acceptance of information technology: system characteristics, user perceptions, and behavioral impacts. International Journal of Man-Machine Studies, 38, 475-487.

Davidson-Shivers, G.V. \& Rasmussen, K.L. (2006). Web-Bassed Learning: Design, Implementation, and Evaluation. New Jersey: Pearson Prentice Hall.

DiMaggio, P.J. \& Powell, W.W. (1983). The iron cage revisited: Institutional isomorphism and collective rationality in organizational fields. American Sociological Review, 48, 2, 147-160.

Fishbein, M. \& Ajzen, I. (1975). Belief, Attitude, Intention, and Behavior: An Introduction to Theory and Research. Reading, MA: Addison-Wesley.

Jan, P., Lu, H. \& Chou, T. (2012). The adoption of e-learning: An institutional theory perspective. The Turkish Online Journal of Educational Technology, 11, 3, 326-343. Diambil pada tanggal 18 September 2012, dari http://www.tojet.net/articles/

Kementerian Pendidikan Nasional. (2010). Rencana Strategis Kementerian Pendidikan Nasional 2010-2014.

Keramati, A., Afshari-Mofrad, M. \& Kamrani, A. (2011). The role of readiness factors in e-learning outcomes: An empirical study. Computers \& Education, 57, 1919-1929.

Kostik, B., Tokareva, N., Boutin, F., et al. (2009). ICT application in TVET. Dalam Maclean, R. \& Wilson D.N. (Eds.), International Handbook of Education for the Changing World of Work (pp.18791894). London: Springer Science Business Media
Ming, T.S., Hall, C., Azman, H., et.al. (2010). Supporting smart school teachers' continuing professional development in and through ICT: A model for change. International Journal of Education and Development using Information and Communication Technology, 6, 2, 1-16.

Moore, G.C. \& Benbasat, I. (1991). Development of an instrument to measure the perception of adoption an information technology innovation. Information Research, 2, 3, 192-222.

Nairne, J.S. (2009). Psychology ( $5^{\text {th }}$ ed.). California: Thomson Wadworth.

Punnoose, A.C. (2012). Determinants of intention to use e-learning based on the technology acceptance model. Journal of Information Technology Education Research, 11, 301-337.

Roca, J.C. \& Gagne, M. (2008). Understanding e-learning continuance intention in the workplace: A selfdetermination theory perspective. Computers in Human Behavior, 24, 1585-1604.

Sahin, S. (2010), Development and Factor Analysis of an Instrument to Measure Preservice Teachers' Perceptions of Learning Objects. Eurasia Journal of Mathematics, Science \& Technology Education, 6(4), 253-261.

Smaldino, S.E., Lowther, D.L. \& Russell, J.D. (2008). Instructional technology and media for learning. New Jersey: Pearson Prentice Hall.

Sun, H. \& Zhang, P. (2006). The role of moderating factors in user technology acceptance. International Jurnal of Human-Computer Studies, 64, 53-78

Tan, P.J.B., Potamites, P.R. \& Wens-Chi, L. (2012). Applying the TAM to understand the factors affecting use of online banking in the Pescadores. ARPN Journal of Science and Technology, 2, 11, 1022-1028.

Teo, T. (2009). Modelling technology acceptance in education: A study of preservice teachers. Computers \& Education, 52, 302-312. 
Venkatesh,V \& Bala, H. (2008). Technology acceptance model 3 and a research agenda on interventions. Decision Sciences, 39, 2, 186-204.

Venkatesh,V., Morris, M.G., Davis, G.B., et al. (2003). User acceptance of information technology: toward a unified view. MIS Quarterly, 27, 3, 425-478.

Workman, M. (2014). New media and the changing face of information technology use: The importance of task pursuit, social influence, and experience. Computers in Human Behavior, 31, 111-117
Yang, H. \& Choi, I. (2001, December). Revisiting technology acceptance model with social influence factors. PACIS 2001 Proceedings, 509-523. Diambil pada tanggal 24 Februari 2013, dari http:// aisel.aisnet.org/pacis 2001.

Zarini, M., Wilson, D.N., Mar, N.Y., et al. (2009). Overview: The growing role of ICTs in education and training. Dalam Maclean, R. \& Wilson D.N. (Eds.), International Handbook of Education for the Changing World of Work (pp.18351846). London: Springer Science Business Media. 